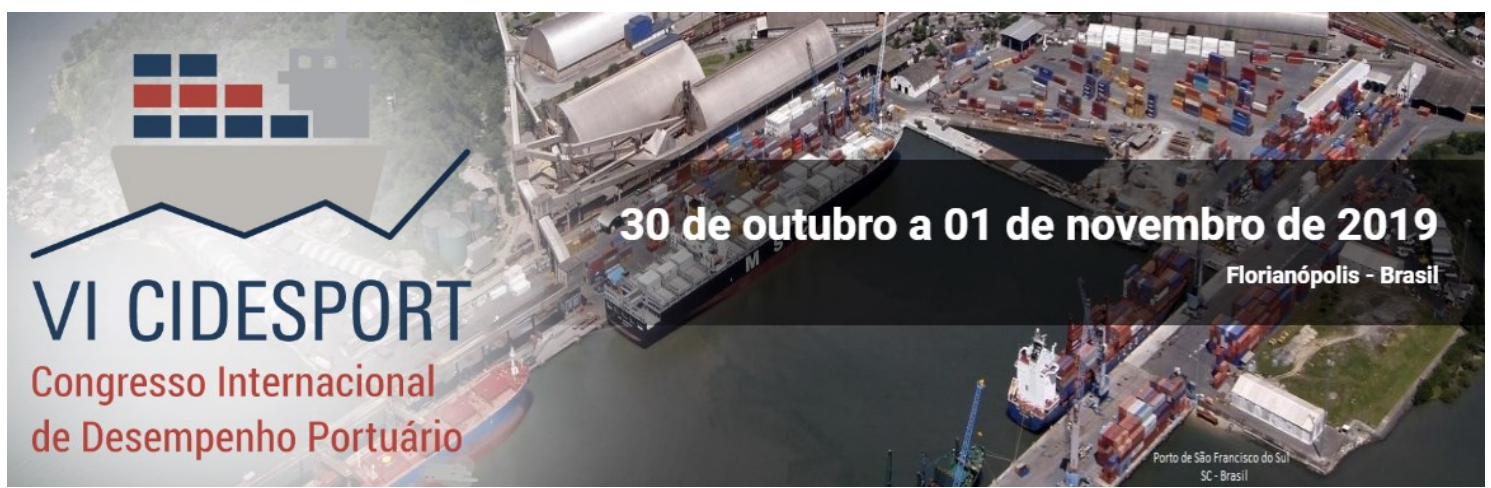

\title{
DIAGNÓSTICO DOS ACIDENTES ENVOLVENDO DERRAME DE ÓLEO AO MAR NO COMPLEXO PORTUÁRIO DE SÃO LUÍS
}

\author{
Diego Lima Matos \\ Secretaria de Estado do Meio Ambiente e Recursos Naturais do Maranhão - SEMA \\ Darliane Ribeiro Cunha \\ Secretaria de Estado do Meio Ambiente e Recursos Naturais do Maranhão - SEMA \\ Sérgio Cutrim \\ Secretaria de Estado do Meio Ambiente e Recursos Naturais do Maranhão - SEMA
}

Resumo: Dentre os diversos aspectos ambientais relacionados ao transporte marítimo e logística portuária de combustíveis derivados do petróleo encontra-se aquele que, por mais que não seja rotineiro, pode causar sérios impactos ambientais, que é o risco de derrame de óleo em corpos hídricos. Tendo em vista que, pelo menos em curto prazo, como não há possibilidade de retirada dessa fonte de energia não renovável oriunda de combustíveis fósseis, em virtude desta fonte ser um dos principais motores da economia atual, surge a necessidade de se gerenciar esse risco. Dessa forma, o presente trabalho visa diagnosticar e analisar a situação dos sistemas de gerenciamento de risco de derrame de óleo das empresas que atuam no Complexo Portuário de São Luís (CPSL). Como fonte de coleta de dados para a pesquisa, utilizou-se notícias de jornais e informes dos incidentes envolvendo derrame de óleo nos últimos 30 anos (1987-2017). Como resultado, constatou-se que a maioria das origens dos casos encontrados em notícias e informes são de navios e dutos, enquanto os portes de vazamentos foram enquadrados pelas notícias, em grande parte, como pequenos. Quanto aos locais de ocorrência houve predominância de acidentes no Porto do Itaqui e na região da baía de São Marcos. Quanto ao intervalo de tempo entre os acidentes, encontrou-se um hiato de, aproximadamente, dois anos entre um evento e outro.

Palavras-chave: Acidente Ambiental. Derrame de óleo. Portos.

\section{INTRODUÇÃO}

Um dos principais pilares da sociedade atual é a energia. Ela se faz necessária para o desenvolvimento de bens a partir dos recursos ambientais e para oferecer muitos outros serviços demandados pela humanidade. $O$ crescimento econômico e o aumento dos padrões de vida são processos complexos que dividem algo em comum: a necessidade de um fornecimento satisfatório e confiável de energia. Atualmente, $90 \%$ das fontes comerciais de energia utilizadas mundialmente são oriundas de combustíveis fósseis (carvão, gás natural e petróleo) (HINRICHS \& KLEINBACH, 2003).

* A revisão gramatical, ortográfica, ABNT ou APA foi realizada pelos autores. 


\section{CIDESPORT/2019 \\ Congresso Internacional \\ de Desempenho Portuário}

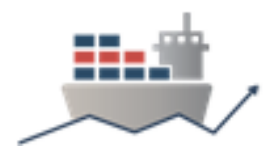

Diante deste contexto, essa demanda de derivados de petróleo é atendida principalmente pelo transporte marítimo que, durante as operações portuárias de movimentação de granéis líquidos (em sua maioria composta por petróleo, produtos químicos e outras substâncias perigosas) há a possibilidade de ocorrência de acidentes que podem poluir as águas e a chance de provocar incêndios e explosões, além de outros danos à flora, fauna e o ser humano. Com relação aos processos de atracação e desatracação, visando as operações supracitadas, os riscos de acidentes são constantes, resultando destes impactos ambiental de magnitudes consideráveis, principalmente no caso de operações de carga e descarga de combustíveis (BNB, 1999).

Existe um maior número de ocorrências no brasil relacionados a acidentes ambientais envolvendo o transporte rodoviário e o aquaviário. Porém, os ambientes naturais mais afetados por esses acidentes com produtos químicos, em especial óleo, é o ecossistema aquático, com aproximadamente, mais de 200 acidentes por ano. As maiores ocorrências envolvem óleo diesel e gasolina, respectivamente (IBAMA, 2010).

A presente pesquisa está relacionada com uma investigação sobre acidentes com óleo ocorridas no Complexo Portuário de São Luís (CPSL), compreendido pelo porto público do Itaqui e dois terminais privados: Terminal Marítimo de Ponta da Madeira (da empresa VALE) e Terminal da ALUMAR. Nesse complexo atracam rotineiramente vários navios de grande calado, transportando diferentes tipos de produtos industrializados, além de diversos produtos como minérios e derivados do petróleo.

Para a prevenção de acidentes existem obrigações ambientais, como licenças ambientais, licenciamento de dragagem, instalação e operacionalização de unidades de gestão ambiental, planos de gerenciamento de resíduos, auditorias ambientais, programas de gerenciamento de riscos, planos de controle de emergência e planos de monitoramento ambiental, programa de prevenção de riscos ambientais e o Plano de Emergência Individual (PEI). Apesar dessa quantidade de exigências ainda são grandes as não-conformidades (KITZMANN \& ASMUS, 2006).

Assim, tendo em vista as prerrogativas abordadas anteriormente, com possibilidade de oferecer subsídios técnicos às atividades de prevenção e resposta a derrame de óleo desenvolvidas na região da baia de São Marcos, somado aos possíveis benefícios tangíveis às populações locais e a proteção do meio ambiente, é que se destaca a importância dessa pesquisa no sentido de diagnosticar a situação presente das empresas que atuam no Complexo Portuário de São Luís face a gestão ambiental dos riscos de derrame de óleo.

Diante deste contexto, o estudo tem como objetivo identificar as origens, dimensões, periodicidade e locais dos acidentes envolvendo derrame de óleo ao mar na região do Complexo Portuário de São Luís (CPSL) nos últimos 30 anos.

\section{REFERENCIAL TEÓRICO}

A presente seção aborda dois temas para o desenvolvimento da pesquisa: petróleo e seus derivados e riscos e acidentes com derrame de óleo ao mar. São importantes para a compreensão do contexto envolvendo a cadeia produtiva do petróleo, sua utilização no transporte marítimo, seus riscos e principais tipos de acidentes. 
VI CIDESPORT/2019

Congresso Internacional

de Desempenho Portuário

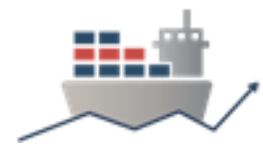

\subsection{Petróleo e derivados}

No Brasil, a história da exploração do petróleo tem início em 1858, com a edição do Decreto $n^{\circ} 2.266$, autorizando a extração de material betuminoso próximo ao Rio Marau, na então província da Bahia, para produção de querosene. No entanto, o primeiro poço somente foi perfurado em 1897, no município de Bofete, estado de São Paulo, com profundidade de $488 \mathrm{~m}^{3}$ e produção de $0,5 \mathrm{~m}^{3}$ de óleo (THOMAS, 2004).

$\mathrm{Na}$ década de 80 e 90, com o advento de novas tecnologias, os custos de exploração e produção do petróleo foram drasticamente reduzidos, sendo que em 1996 as reservas mundiais provadas eram 60\% maiores que em 1980 . Nesse mesmo período os custos de produção foram diminuídos em, pelo menos, $60 \%$. Dessa forma, com a redução dos custos de exploração e a descoberta de novas reservas, além da melhoria de processos petroquímicos, houve um grande aumento na demanda por derivados de petróleo como plásticos, solventes, detergentes, dentre outros, mas, principalmente, combustíveis (THOMAS, 2004).

No ano de 2016 (Figura 01), o Brasil teve uma oferta interna bruta de energia da ordem de 288,3 milhões de toneladas equivalentes de petróleo ( $10^{6}$ tep), no qual mais de um terço desse total teve origem no petróleo e seus derivados, sendo que essa fonte não-renovável de energia ofertou mais de $105 \times 10^{6}$ tep à demanda interna nacional (EPE, 2017).

As outras fontes que ocupam, respectivamente, o segundo e o terceiro lugar na oferta energética nacional são oriundos de fontes renováveis de energia, representados pelos produtos da cana $\left(50,3 \times 10^{6}\right.$ tep) e em seguida pela fonte hidráulica e elétrica $\left(36,3 \times 10^{6}\right.$ tep). Do outro lado desse fluxo, os setores que, conjuntamente, responderam por mais da metade dessa demanda enérgica foram as industriais e os transportes (EPE, 2017).

Figura 01 - Fluxo energético nacional no ano base de 2016 (com valores em milhões de toneladas equivalentes de petróleo e respectivos percentuais). 
VI CIDESPORT/2019

Congresso Internacional

de Desempenho Portuário
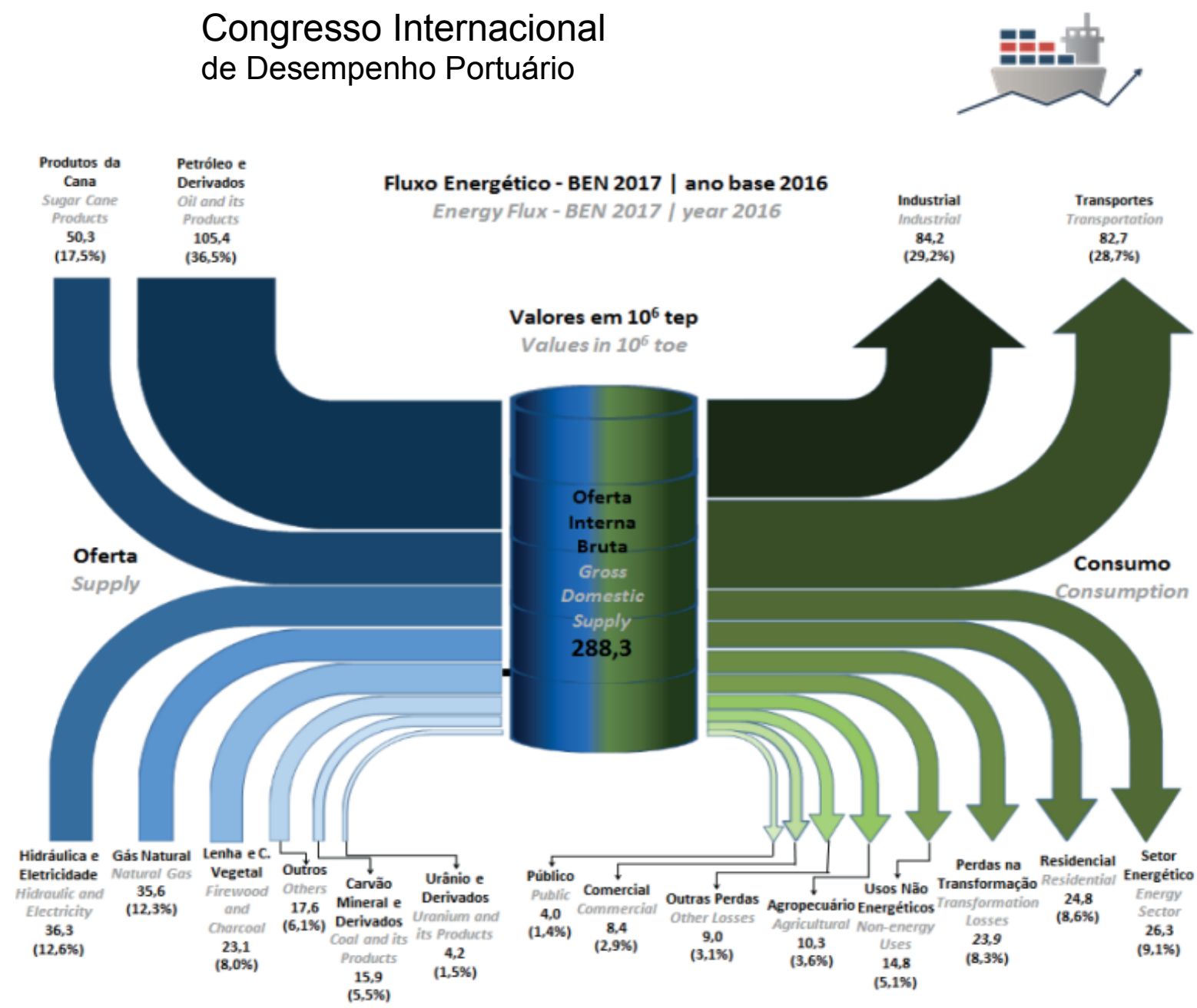

Fonte: EPE (2017).

Assim, de forma simplificada, o petróleo pode ser caracterizado com uma mistura hidrocarbonetos, ou seja, compostos orgânicos formados por carbono e hidrogênio, sendo que os principais grupos componentes do petróleo são os hidrocarbonetos saturados (parafinas, isoparafinas e naftenos), os hidrocarbonetos aromáticos, as resinas e os asfaltenos. (SZKLO \& ULLER, 2008).

Apesar de todos os tipos de petróleo conterem os mesmos tipos de hidrocarbonetos, a proporção relativa de cada grupo de hidrocarboneto varia conforme a origem do petróleo, afetando inclusive suas propriedades físico-químicas (SZKLO \& ULLER, 2008).

Dentre as principais desvantagens de combustíveis derivados do petróleo está a questão da emissão de Gases do Efeito Estufa (GEE), principalmente dióxido de carbono $\left(\mathrm{CO}_{2}\right)$ durante o processo de combustão, que contribuem para o aumento do aquecimento global. Entretanto uma outra desvantagem dos combustíveis derivados do petróleo reside justamente no fato da possibilidade de contaminação de ambientes costeiros por conta de cenários de vazamentos de óleo, principalmente por conta do transporte marítimo de petróleo (SPIRO \& STIGLIANI, 2009).

Os poluentes que afetam 0 meio ambiente marinho podem ser enquadrados em vários critérios, mas o principal deles é aquele relacionado a persistência do poluente no ambiente. Dessa forma os poluentes podem ser divididos em seis grandes grupos (VIDIGAL, 2006):

- emissões aéreas: representado principalmente pelo material particulado emitido por chaminés através de processos de combustão;

- sólidos: composto majoritariamente por todos os resíduos sólidos;

- bioinvasor: introdução de espécies exóticas; ou seja, não nativas em um ecossistema diferente da sua origem; 


\section{CIDESPORT/2019 \\ Congresso Internacional \\ de Desempenho Portuário}

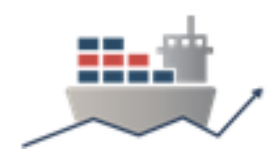

- facilmente dissipáveis: ácidos e bases inorgânicas e calor; radioativos; e,

- conservativos: como, por exemplo, metais pesados, pesticidas e

- não conservativos ou biodegradáveis: substâncias passíveis de degradação biológica.

Especificamente, os poluentes marítimos não conservativos são compostos especialmente por substâncias ricas em carbono, fósforo e nitrogênio, sendo que tais poluentes em diversos tipos de efluentes líquidos (esgotos domésticos e industriais), rejeitos da atividade agrossilvipastoril, detergentes, e produtos da indústria química e petroquímica (VIDIGAL, 2006).

Dessa forma, o petróleo e seus derivados são considerados como poluentes marítimos não conservativos; ou seja, quando o óleo entra em contato com a água do mar podem ocorrer vários processos físico-químico e biológico, em períodos e intensidades variáveis. Logo, quanto maior o número de átomos de carbono na composição do petróleo, menor será sua taxa de evaporação e solubilidade, com menos susceptibilidade a biodegradação e maior será a sua persistência no ambiente marinho (VIDIGAL, 2006).

Anualmente, em todo o mundo, estima-se que cerca de mais de 600 milhões de toneladas de petróleo e derivados, como combustíveis e lubrificantes, entrem em contato com o mar, tendo como origem as mais diversas fontes. Porém, os maiores vazamentos de óleo que se originaram de naufrágio ou colisão de superpetroleiros foram os mais catastróficos para o ambiente marinho. Tais acidentes levaram a regulamentos mais severos, como a exigência de casco duplo para petroleiros para novos navios (CASTRO \& HUBER, 2012).

Em 1978 ocorreu o naufrágio de um superpetroleiro, chamado Amoco Cadiz, que vazou cerca de 230 mil toneladas de petróleo bruto próximo do litoral francês. Já no ano de 1989 o navio Exxon Valdez lançou mais de 35 mil toneladas de petróleo bruto na extensão da costa sul do Alasca, afetando diversas formas de vida selvagem. Mais recentemente, em 2002, o navio Prestige naufragou na costa da Espanha, derramando mais de 63 mil toneladas de óleo (e afundando com outras 40), criando uma mancha de mais de $30 \mathrm{~km}$ de extensão, e deixando mais de $100 \mathrm{mil}$ desempregados por conta dos impactos à aquicultura e pesca (CASTRO \& HUBER, 2012).

\subsection{Riscos e acidentes com derrame de óleo ao mar}

Durante a história da civilização ocidental foram cunhadas diversos termos para definir o conceito de risco, mas a partir da Idade Média surgiram expressões como rozik, que nome idioma persa significa destino, ou resecum, que em latim é entendido como perigo, e até mesmo rhiza, que em grego pode significar penhasco (SILVA, 2004).

Silva (2014) afirma que o risco é um evento negativo e danoso possa vir a acontecer em uma certa faixa de probabilidade. O perigo é o dano ou ameaça em si. Em linhas gerais, os riscos podem ser classificados a partir das seguintes categorias (SILVA, 2004):

- quanto a natureza de seus agentes: físico, químico, biológico e psicossociais;

- quanto a fonte geradora: produção, armazenagem, transporte, manuseio, comercialização, etc.; 


\section{CIDESPORT/2019}

Congresso Internacional

de Desempenho Portuário

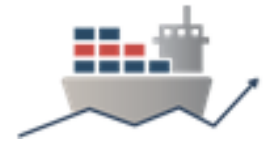

- quanto ao sujeito do risco: bem-estar público, segurança pública, saúde humana, administrativo, financeiro, ocupacional e ambiental.

Os riscos ambientais podem ser divididos em naturais (atmosférico, hidrológico, biológico e sideral) ou tecnológicos (agudos e crônicos) (SÁNCHEZ, 2006).

Desde a década de 70 o mundo presenciou diversos desastres ambientais de origem tecnológica (Quadro 01), das mais variadas atividades e produtos envolvidos, desde navios, dutos, plataformas, indústrias e termelétricas, com produtos como água (em barragem) até substâncias radioativas (SÁNCHEZ, 2006; POFFO, 2002).

Destaca-se que, dos oito acidentes mais significativos envolvendo vazamento de petróleo no mundo, quatro foram no Brasil, envolvendo dois dutos, uma plataforma de extração e uma base de distribuição de combustíveis. No entanto, o primeiro registro brasileiro oficial de acidente envolvendo navios, e um dos piores no cenário nacional, foi em 1978, no Canal de São Sebastião, litoral norte de São Paulo, com cerca de 6.000 toneladas óleo que vazaram do navio Brazilian Marina (SÁNCHEZ, 2006; POFFO, 2002). 
VI CIDESPORT/2019

Congresso Internacional

de Desempenho Portuário

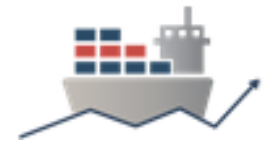

Quadro 01 - Relação de alguns acidentes tecnológicos de consequências desastrosas.

\begin{tabular}{|c|c|c|c|}
\hline ATA & $\overline{C A L}$ & /ENTO & IAS \\
\hline $01 / 06 / 1974$ & $\begin{array}{l}\text { Flixboroug, } \\
\text { UK }\end{array}$ & $\begin{array}{l}\text { Explosão de uma nuvem de } \\
\text { cerca de } 40 t \text { de ciclohexano } \\
\text { em uma indústria química }\end{array}$ & $\begin{array}{l}28 \text { mortos, } 89 \text { feridos, } \\
2.450 \text { casas afetadas em } \\
\text { um raio de } 50 \mathrm{~km}\end{array}$ \\
\hline 10/07/1976 & ilia & $\begin{array}{ll}\text { Vazamento } & \text { de } \\
\text { tetraclorodibenzodioxina }\end{array}$ & $\begin{array}{l}736 \text { pessoas evacuadas, } \\
190 \text { intoxicadas }\end{array}$ \\
\hline 16/03/1978 & $\begin{array}{l}\text { osta } \\
\text { anco- } \\
\text { glesa }\end{array}$ & $\begin{array}{l}\text { Derramamento de óleo do } \\
\text { navio Amoco-Cadiz ( } 223.000 \\
\text { t) }\end{array}$ & $\begin{array}{l}30 \text { mil aves mortas e } 230 \\
\text { peixes e frutos do mar }\end{array}$ \\
\hline 28/03/1979 & $\begin{array}{l}\text { ensilvânia, } \\
\text { UA }\end{array}$ & $\begin{array}{l}\text { Ameaça de fuga de } \\
\text { radioatividade em Threee } \\
\text { Mile }\end{array}$ & $\begin{array}{l}250 \text { mil pessoas } \\
\text { evacuadas num raio de } 8 \\
\mathrm{~km}\end{array}$ \\
\hline 10/11/1979 & a, & $\begin{array}{llr}\text { Descarrilamento de } & \text { dois } \\
\text { vagões seguido } & \text { de } \\
\text { explosões } & & \\
\end{array}$ & $\begin{array}{l}240 \text { mil pessoas } \\
\text { evacuadas }\end{array}$ \\
\hline $25 / 02 / 1984$ & ace & $\begin{array}{l}\text { Vazamento de } 700 \text { mil litros } \\
\text { de gasolina de um duto da } \\
\text { Petrobras, seguido de } \\
\text { incêndio }\end{array}$ & 4 mil ferido \\
\hline $19 /$ & $\begin{array}{l}\text { Cidade do } \\
\text { México, } \\
\text { México }\end{array}$ & Explosão de gás & $\begin{array}{lrr}452 \quad \text { mortos, } & 4.258 \\
\text { feridos, } & 31 & \text { mil } \\
\text { evacuados } & & \end{array}$ \\
\hline $02 /$ & opal, & $\begin{array}{l}\text { Vazamento de Is } \\
\text { Metila }\end{array}$ & 1.762 mortos \\
\hline $26 / 04 / 1986$ & $\begin{array}{l}\text { eernobil, } \\
\text { crânia }\end{array}$ & $\begin{array}{l}\text { Vazamento } \\
\text { radioatividade }\end{array}$ & $\begin{array}{l}32 \text { mortos, } 135 \text { mil } \\
\text { evacuados }\end{array}$ \\
\hline 13/09/1987 & $\begin{array}{l}\text { Goiâ } \\
\text { Brasi }\end{array}$ & sio-137 & $\begin{array}{l}4 \text { mortos, } 129 \text { pessoas } \\
\text { contaminadas } \quad \text { (com } \\
\text { sintomas) e outras } 1.000 \\
\text { pessoas expostas }\end{array}$ \\
\hline 24/03/1989 & $\begin{array}{l}\text { Alasca, } \\
\text { EUA }\end{array}$ & $\begin{array}{l}\text { Vazamento do petroleiro } \\
\text { Exxon-Valdez }\end{array}$ & $\begin{array}{l}1.000 \mathrm{~km} \text { de costa } \\
\text { poluída, mais de } 35 \mathrm{mil} \\
\text { aves }\end{array}$ \\
\hline 18/01/2000 & $\begin{array}{l}\text { Duque de } \\
\text { Caxias, } \\
\text { Brasil }\end{array}$ & $\begin{array}{l}\text { Vazamento de } 1.300 .000 \\
\text { litros de óleo combustível de } \\
\text { um duto (da REDUC) na baía } \\
\text { de Guanabara }\end{array}$ & $\begin{array}{l}\text { Contaminação de } \\
\text { praias, mangues, danos } \\
\text { à pesca e ao turismo }\end{array}$ \\
\hline 13/11/2002 & $\begin{array}{l}\text { aliza, } \\
\text { spanha }\end{array}$ & $\begin{array}{l}\text { Vazamento de } 10.000 .000 \\
\text { de litros de óleo do navio } \\
\text { Prestige }\end{array}$ & $\begin{array}{l}\text { Morte de mais de } 20.000 \\
\text { aves e mais de } 700 \\
\text { praias contaminadas }\end{array}$ \\
\hline 20/04/2010 & $\begin{array}{l}\text { Golfo do } \\
\text { México, } \\
\text { EUA }\end{array}$ & $\begin{array}{l}\text { Vazamento de } 5.000 .000 \text { de } \\
\text { barris de petróleo }\end{array}$ & $\begin{array}{l}11 \text { pessoas mortas e } \\
\text { outras } 14 \text { feridas, } \\
\text { milhares de animais } \\
\text { mortos e um impacto } \\
\text { para a economia de mais } \\
\text { de } 1 \text { bilhão de dólares }\end{array}$ \\
\hline
\end{tabular}


VI CIDESPORT/2019

Congresso Internacional

de Desempenho Portuário

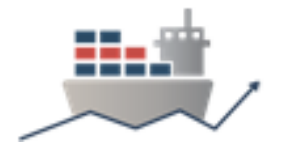

\begin{tabular}{|c|c|c|c|}
\hline $09 / 11 / 2011$ & $\begin{array}{l}\text { Bacia de } \\
\text { Campos, } \\
\text { Brasil }\end{array}$ & $\begin{array}{l}\text { Vazamento de } 3.700 \text { de } \\
\text { barris de petróleo de uma } \\
\text { plataforma da Chevron }\end{array}$ & $\begin{array}{l}\text { Geração de mancha de } \\
\text { óleo de } 168 \mathrm{~km}^{2} \text {, com } \\
\text { multa de mais de } 300 \\
\text { milhões de reais à } \\
\text { empresa }\end{array}$ \\
\hline $02 / 04 / 2015$ & $\begin{array}{l}\text { Santos, } \\
\text { Brasil }\end{array}$ & $\begin{array}{l}\text { Incêndio no terminal da } \\
\text { Ultracargo, que durou } 9 \text { dias, } \\
\text { com vazamento de bilhões } \\
\text { de litros de água (utilizadas } \\
\text { para extinção do fogo) } \\
\text { contendo resíduos de } \\
\text { combustíveis e produtos } \\
\text { químicos utilizados nos } \\
\text { extintores }\end{array}$ & $\begin{array}{l}\text { Com impactos imediatos } \\
\text { da seguinte ordem: } 8 \\
\text { toneladas de peixes } \\
\text { mortos, centenas de } \\
\text { pessoas com problemas } \\
\text { respiratórios e multa de } \\
22 \text { milhões de reais. } \\
\text { Especialistas afirmam } \\
\text { que outros impactos } \\
\text { poderão perdurar ainda } \\
\text { por cerca de } 10 \text { anos. }\end{array}$ \\
\hline $05 / 11 / 2015$ & $\begin{array}{l}\text { Mariana, } \\
\text { Brasil }\end{array}$ & $\begin{array}{l}\text { Liberação de } 60 \text { milhões de } \\
\text { metros cúbicos de rejeitos de } \\
\text { minério, originados de uma } \\
\text { barragem da SAMARCO. }\end{array}$ & $\begin{array}{l}17 \text { mortos, centenas de } \\
\text { desabrigados e mais de } \\
230 \text { municípios afetados } \\
\text { ao longo da bacia do Rio } \\
\text { Doce }\end{array}$ \\
\hline
\end{tabular}

Fonte: Sánchez (2006) e Gonçalves (2017).

Ressalta-se ainda que, na baía de São Marcos, em São Luís, estado do Maranhão, existem registros de ocorrências de acidentes ambientais envolvendo derrame de óleo desde a década cinquenta e oitenta. O primeiro desses registros ocorreu em 16/03/1954, a cerca de 500 metros do cais da Praia Grande, envolvendo o navio petroleiro denominado Maria Celeste que carregava algo entorno de 1.000 barris com parafina e 3.000 barris com combustível (AZOUBEL, 2008, 2017).

O navio Maria Celeste se incendiou durante três dias, por conta de um provável curto circuito durante uma operação de transbordo de combustíveis em tonéis. Como consequência desse acidente, 14 pessoas morreram, tambores foram lançados a mais de $35 \mathrm{~m}$ de altura, e foi gerado um enorme vazamento de óleo no mar (AZOUBEL, 2008, 2017).

\section{PROCEDIMENTOS METODOLÓGICOS}

O estudo enquadra-se na abordagem qualitativa. Para a coleta dos dados foram utilizados os procedimentos de pesquisa bibliográfica e documental com a utilização da técnica de análise de conteúdo. Foram utilizadas como fonte as notícias jornalísticas e informes publicadas no período de 1987 a 2017 nos seguintes meios: Jornal Pequeno; Jornal do Brasil; Tribunal Marítimo; Folha de São Paulo; O Estado do Maranhão; PortosMA; Imirante; Ecopress; Terra; Jornal da Globo; G1 Maranhão; EMAP e ALUMAR.

Dessa forma, realizou-se um levantamento das ocorrências (acidentes e incidentes), a partir de notícias jornalísticas e informes, que gerassem algum vazamento de óleo, ou que tivessem potencial para tal, na região do Complexo Portuário de São Luís e baia de São Marcos, no período de 1987 a 2017. Foram encontradas e compiladas 15 (quinze) ocorrências que atendiam esses critérios, no qual foram extraídas algumas informações como: volume vazado por período, 


\section{CIDESPORT/2019 \\ Congresso Internacional \\ de Desempenho Portuário}

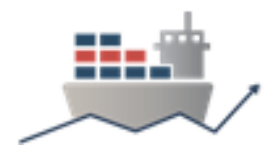

principais locais das ocorrências, fontes originárias dos riscos, tamanho dos vazamentos e probabilidade de ocorrências de acidentes.

Acidente Ambiental, Derrame de Óleo, Portos.

\section{RESULTADOS}

Foram encontradas, no período de 1987 a 2017, 15 (quinze) situações ocorridas no Complexo Portuário de São Luís e baia de São Marcos que tiveram vazamento de óleo, ou que se envolveram em situações que poderiam levar a tal acontecimento (Quadro 02). De forma, resumida, a esses cenários de acidentes e incidentes nessa região e nesse período, para fins de facilitar a comunicação, essas situações serão denominadas de ocorrências.

Quadro 02 - Relação dos principais acidentes que tiveram derrame de óleo ao mar, ou que apresentaram um alto potencial de emissões oleosas, na região do CPSL, conforme notícias publicadas em sites e/ou jornais.

\begin{tabular}{|c|c|c|c|}
\hline DATA & LOCAL & EVENTO & CONSEQUÊNCIAS \\
\hline $31 / 03 / 1987$ & $\begin{array}{l}\text { Banco de } \\
\text { areia } \\
\text { conhecido } \\
\text { como } \\
\text { "Cavalos", } \\
\text { Baia de } \\
\text { São Marcos }\end{array}$ & $\begin{array}{l}\text { Navio coreano Hyunday } \\
\text { New World, minero- } \\
\text { graneleiro, encalha em } \\
\text { um banco de areia, } \\
\text { possivelmente provocada } \\
\text { por problemas na casa de } \\
\text { máquinas. }\end{array}$ & $\begin{array}{l}\text { Provável vazamento de } \\
\text { óleo ao mar, pois os } \\
\text { destroços até hoje } \\
\text { encontram-se no local, mas } \\
\text { já encobertos pela areia. }\end{array}$ \\
\hline 16/11/1989 & $\begin{array}{l}\text { Banco de } \\
\text { areia } \\
\text { conhecido } \\
\text { como } \\
\text { "Lanzudos", } \\
\text { Baia de } \\
\text { São Marcos }\end{array}$ & $\begin{array}{l}\text { O navio Trombetas, da } \\
\text { empresa Norsul, } \\
\text { originária do Porto de } \\
\text { Trombetas-PA, carregava } \\
30 \text { mil toneladas de } \\
\text { bauxita para a Alumar, } \\
\text { quando chocou-se com } \\
\text { um banco de areia, } \\
\text { entrando água na casa de } \\
\text { máquinas. }\end{array}$ & $\begin{array}{l}\text { Dias depois do ocorrido o } \\
\text { navio partiu-se ao meio. }\end{array}$ \\
\hline 1990 & $\begin{array}{l}\text { Banco de } \\
\text { areia } \\
\text { conhecido } \\
\text { como } \\
\text { "Cavalos", } \\
\text { Baia de } \\
\text { São Marcos }\end{array}$ & \begin{tabular}{lrr} 
O Navio & Orad & Nassau, \\
chocou-se & com & os \\
destroços & do & já \\
naufragado & \multicolumn{3}{c}{ navio } \\
Hyunday New World.
\end{tabular} & $\begin{array}{l}\text { Carregava } 33 \text { mil toneladas } \\
\text { de óleo diesel, sendo que } \\
\text { parte da sua carga foi } \\
\text { jogada ao mar. }\end{array}$ \\
\hline $06 / 11 / 1993$ & $\begin{array}{l}\text { Baia de } \\
\text { São Marcos }\end{array}$ & $\begin{array}{l}\text { Naufrágio do rebocador } \\
\text { Rigel, após chocar-se } \\
\text { com o navio Mount Athos. }\end{array}$ & Morte de 2 tripulantes. \\
\hline $11 / 11 / 1994$ & $\begin{array}{l}\text { Ponta da } \\
\text { Madeira }\end{array}$ & $\begin{array}{l}\text { Navio Trade Daring, } \\
\text { ancorado no porto de } \\
\text { Ponta da Madeira, partiu- } \\
\text { se ao meio durante um }\end{array}$ & $\begin{array}{l}\text { Despejo de mais de } 30 \text { mil } \\
\text { toneladas de minério de } \\
\text { ferro em um determinado } \\
\text { ponto da baia de São }\end{array}$ \\
\hline
\end{tabular}


VI CIDESPORT/2019

Congresso Internacional

de Desempenho Portuário

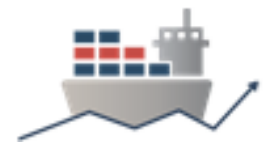

\begin{tabular}{|c|c|c|c|}
\hline & & $\begin{array}{l}\text { processo de } \\
\text { carregamento de minério } \\
\text { de ferro. As possíveis } \\
\text { causas para isso foram }\end{array}$ & $\begin{array}{l}\text { Marcos. Foram retirados } \\
\text { cerca de } 2 \text { mil toneladas de } \\
\text { óleo O porto de Ponta da } \\
\text { Madeira ficou paralisado } \\
\text { por } 35 \text { dias ( } 25 \text { além do } \\
\text { esperado) }\end{array}$ \\
\hline 29/12/1999 & $\begin{array}{l}\text { Porto do } \\
\text { Itaqui }\end{array}$ & $\begin{array}{l}\text { Falha em tubulação de } \\
\text { óleo MF } 380 \text { da Petrobras, } \\
\text { no Porto do Itaqui. }\end{array}$ & $\begin{array}{l}\text { Vazamento de cerca de } 2 \\
\text { mil litros de óleo ao mar, } \\
\text { restrito a área do porto, na } \\
\text { baía de São Marcos. }\end{array}$ \\
\hline $01 / 06 / 2000$ & $\begin{array}{l}\text { Porto do } \\
\text { Itaqui }\end{array}$ & $\begin{array}{l}\text { Durante abastecimento } \\
\text { do navio Spear, pela } \\
\text { Petrobrás, ocorreu } \\
\text { derramamento de óleo. } \\
\text { Hipótese principal: falha } \\
\text { humana. }\end{array}$ & $\begin{array}{l}\text { Vazamento de cerca de } \\
\text { 5mil litros de óleo ao mar. }\end{array}$ \\
\hline $11 / 04 / 2003$ & $\begin{array}{l}\text { Baia de } \\
\text { São Marcos }\end{array}$ & $\begin{array}{l}\text { Naufrágio do barco } \\
\text { pesqueiro Guadalupe, ao } \\
\text { ser abalroado pelo } \\
\text { cargueiro Chine Steel } \\
\text { Growth, quando } \\
\text { pescavam com rede entre } \\
\text { as boias } 19 \text { e } 24 \text { do canal } \\
\text { de acesso }\end{array}$ & $\begin{array}{l}\text { Dos } 4 \text { tripulantes do barco, } \\
2 \text { estão desaparecidos }\end{array}$ \\
\hline $05 / 09 / 2003$ & $\begin{array}{l}\text { Porto } \\
\text { Itaqui }\end{array}$ & $\begin{array}{l}\text { Navio Antigoni, durante a } \\
\text { madrugada, ao realizar } \\
\text { transferência interna no } \\
\text { tanque de embarcação, } \\
\text { vazou óleo }\end{array}$ & $\begin{array}{l}\text { Cerca de } 10 \text { litros de óleo } \\
\text { vazaram, sendo que foram } \\
\text { utilizados lanchas, barreiras } \\
\text { de contenção } \\
\text { absorventes e barcos } \\
\text { recolhedores de óleo, } \\
\text { inclusive com a realização } \\
\text { de um sobrevoo para } \\
\text { avaliar a extensão da } \\
\text { mancha }\end{array}$ \\
\hline $04 / 11 / 2005$ & $\begin{array}{l}\text { Porto do } \\
\text { Itaqui }\end{array}$ & $\begin{array}{l}\text { Vazamento } \\
\text { combustível MF a partir de } \\
\text { uma válvula de uma } \\
\text { tubulação da Transpetro, } \\
\text { no berço 102, durante } \\
\text { operação de } \\
\text { carregamento do navio } \\
\text { Nicolaus G, no Porto do } \\
\text { Itaqui. Hipótese principal: } \\
\text { fadiga do equipamento. }\end{array}$ & $\begin{array}{l}\text { Emissão de cerca de } 150 \\
\text { litros de óleo ao mar, no } \\
\text { qual houve a colocação de } \\
300 \mathrm{~m} \text { de barreiras de } \\
\text { contenção e } 40 \text { metros de } \\
\text { barreiras absorventes para } \\
\text { evitar que a mancha se } \\
\text { alastrasse entre os berços } \\
102 \text { e } 103 \text {. }\end{array}$ \\
\hline $03 / 12 / 2011$ & $\begin{array}{l}\text { Ponta da } \\
\text { Madeira }\end{array}$ & $\begin{array}{l}\text { Um dos maiores navios do } \\
\text { mundo, o Vale Beijing, } \\
\text { após ser carregado com } \\
\text { minério de ferro, } \\
\text { apresentou }\end{array}$ & $\begin{array}{l}\text { A viagem do navio para a } \\
\text { China foi interrompida, } \\
\text { fazendo com que o navio } \\
\text { fosse levado cerca de } 60 \mathrm{~km} \\
\text { da costa de São Luís, para } \\
\text { que se retirassem cerca de }\end{array}$ \\
\hline
\end{tabular}


VI CIDESPORT/2019

Congresso Internacional

de Desempenho Portuário

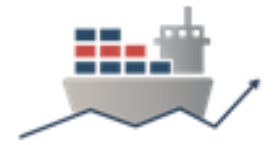

\begin{tabular}{|c|c|c|c|}
\hline & & $\begin{array}{l}\text { rachadura nos tanques de } \\
\text { lastro da popa. }\end{array}$ & $\begin{array}{l}\text { 6mil toneladas } \\
\text { combustível. }\end{array}$ \\
\hline $30 / 09 / 2012$ & $\begin{array}{l}\text { Ponta da } \\
\text { Madeira }\end{array}$ & $\begin{array}{l}\text { Naufrágio da plataforma } \\
\text { Sep Orion, utilizada na } \\
\text { cravação de estacas e } \\
\text { operações de apoio nas } \\
\text { obras do píer IV da Ponta } \\
\text { da Madeira. }\end{array}$ & $\begin{array}{l}\text { Segundo informações da } \\
\text { Capitania dos Portos, cerca } \\
\text { de } 30 \text { mil litros de óleo diesel } \\
\text { foram retirados da } \\
\text { plataforma antes de leva-la } \\
\text { a uma distância de mais de } \\
100 \mathrm{~km} \text { da costa para um } \\
\text { afundamento seguro. }\end{array}$ \\
\hline $25 / 09 / 2016$ & $\begin{array}{l}\text { Porto do } \\
\text { Itaqui }\end{array}$ & $\begin{array}{l}\text { Incêndio de um guindaste } \\
\text { de um operador portuário, } \\
\text { Brazil Marítima, enquanto } \\
\text { fazia uma operação de } \\
\text { descarga de carvão } \\
\text { mineral do navio Nord } \\
\text { Trust, berço } 101 .\end{array}$ & $\begin{array}{l}\text { Houve apenas danos } \\
\text { materiais, sem feridos, } \\
\text { apesar de que a brigada de } \\
\text { incêndio atuou somente } \\
\text { meia hora depois do } \\
\text { ocorrido, sendo que o } \\
\text { operador do guindaste foi } \\
\text { resgatado por um outro } \\
\text { guindaste do próprio navio. }\end{array}$ \\
\hline $20 / 12 / 2016$ & $\begin{array}{l}\text { Porto } \\
\text { Itaqui }\end{array}$ & $\begin{array}{l}\text { A embarcação Atalaia III } \\
\text { adernou }\end{array}$ & $\begin{array}{l}\text { Vazamento de filete de óleo } \\
\text { (da parte externa da } \\
\text { embarcação, e não do } \\
\text { tanque de combustível) ao } \\
\text { mar, que foi contido com } \\
\text { barreiras de contenção e } \\
\text { barreiras absorventes que } \\
\text { foram colocadas }\end{array}$ \\
\hline 07/09/2017 & $\begin{array}{l}\text { TUP } \\
\text { Alumar }\end{array}$ & $\begin{array}{l}\text { Falha no sistema de } \\
\text { resfriamento do gerador } \\
\text { de gás inerte, durante } \\
\text { descarga de óleo BPF do } \\
\text { navio MT Ocean Quest }\end{array}$ & $\begin{array}{l}\text { Vazamento de } 2 \text { litros de } \\
\text { resíduos oleosos, do } \\
\text { gerador de gás do navio, ao } \\
\text { mar, no qual o PEI do TUP } \\
\text { foi acionado para conter a } \\
\text { mancha }\end{array}$ \\
\hline
\end{tabular}

Fonte: Jornal Pequeno (2005, 2011); Jornal do Brasil (1989); Tribunal Marítimo (2014); Folha de São Paulo (1994, 1999); O Estado do Maranhão (2011); PortosMA (2018); Imirante (2003a, 2003b); Ecopress (2000); Terra (2005); Jomal da Globo (2012); G1 Maranhão (2016); EMAP (2016); ALUMAR (2017).

Dessa forma, a compilação dos dados acima (Quadro 02), seguiu a estrutura utilizada por Sánchez (2006) quando da compilação de histórico de acidentes ambientais (data/local/evento/consequência), enquanto que o horizonte temporal (algo entorno de 20 a 30 anos) e os tipos de ocorrências (derrame de óleo) seguiram a linha trabalhadas por Poffo (2002) e, por último, as fontes utilizadas na análise de conteúdo histórico (notícias de jornais) basearam-se, de forma semelhante, na metodologia de coleta de dados de Borges et al. (2017).

Inicialmente, baseado na análise do conteúdo do quadro anterior, foram classificados quatro tipos de fontes de ocorrências de cenários potenciais ou efetivos de derrame de óleo no mar, sendo estes estão: navio, embarcações e maquinários terrestres, dutos (tubulações para movimentação de líquidos combustíveis e inflamáveis) e plataformas (de petróleo ou para instalação de estruturas marinhas). 


\section{CIDESPORT/2019 \\ Congresso Internacional \\ de Desempenho Portuário}

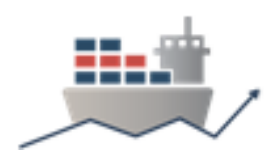

Foram encontrados (Gráfico 01), os seguintes resultados para cada uma das respectivas fontes de ocorrências (quantidades envolvidas): sete navios, quatro embarcações e maquinários terrestres, três dutos e uma plataformas. Os navios estiveram envolvidos em, aproximadamente, cerca de $50 \%$ das fontes de ocorrência, efetivas ou potenciais, de derrame de óleo na baia de São Marcos nos últimos 30 anos.

No entanto, destaca-se, entre os navios envolvidos nas ocorrências supracitadas, grande parte deles (quatro) encontravam-se na primeira década da pesquisa (1987-1996), ainda, muito provavelmente, por conta da legislação mais flexível relativa a construção dos navios, além dos demais problemas possivelmente decorrentes de falha humana, principalmente provocado por problemas de comunicação e treinamento.

Já as embarcações e outros equipamentos terrestres tiveram a maior parte de suas ocorrências (três) nos últimos vinte anos da pesquisa (1997-2017), enquanto os dutos (três) tiveram participação na segunda década da pesquisa (1997-2006) e somente uma plataforma naufragou no ano de 2012.

O Gráfico 01 mostra a predominância de fontes de derrame de óleo originária predominantemente de navios e embarcações, no entanto, ao longo do tempo, tais ocorrências foram diminuindo consideravelmente, sendo que nas últimas duas décadas da pesquisa houve um aumento da participação nos dutos nessas ocorrências de derrames de óleo.

Gráfico 01 - Fontes de ocorrências de cenários potenciais ou efetivos de derrame de óleo no mar na região do Complexo Portuário de São Luís (1987-2017).

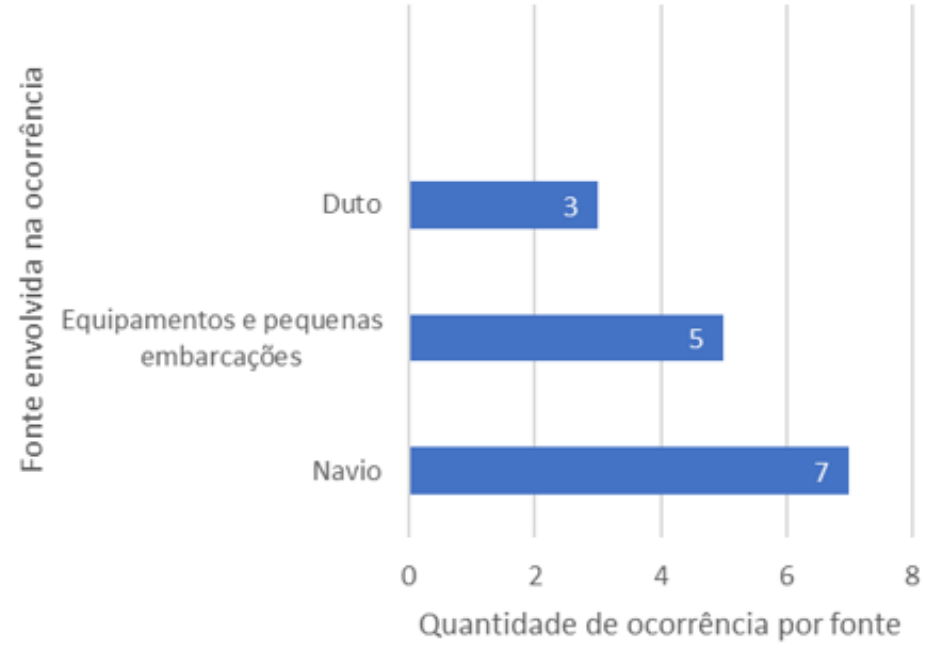

Fonte: Dados da pesquisa.

Em relação aos navios envolvidos nas ocorrências constantes no gráfico anterior, em pesquisa em sites de busca sobre informações de navios (MARINE TRAFFIC e VESSEL FINDER), foi possível identificar que, dos 7 navios envolvidos, 4 foram construídos entre as décadas de 1970 e 1980, e foram justamente esses quatro que tiveram mais avarias e chegaram a naufragar (ou por colisão/albarroamento, ou mesmo por falha operacional/estrutural), sendo que três, dentre os quatro, resultaram, possivelmente, nos maiores portes de volumes de óleo derramados estimados.

Quanto aos outros três navios envolvidos, devido a divergências de nomenclaturas entre as notícias (além de possíveis mudanças de bandeira), não foi possível identificar, com precisão, a data exata de construção, no entanto, estima-se 


\section{CIDESPORT/2019}

Congresso Internacional

de Desempenho Portuário

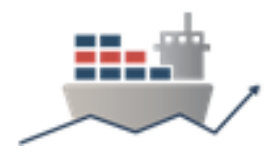

que esses últimos tenham sido construídos depois de 1990. Vale ressaltar que as regras e diretrizes para construção de navios mais seguros para cenários de derrame de óleo e transporte adequado de produtos perigosos entraram em vigor em meados da década de 1980 (MARPOL 73/78, em vigor desde 1983, e SOLAS 74/88, vigente desde 1986).

Apesar do presente estudo não abordar as possíveis causas dessas ocorrências, ressalta-se que um estudo realizado por Eliopoulou et al. (2016) aponta que, no caso de navios, grande parte dos acidentes envolvendo esse modal de transporte de carga ocorreu por conta de falha de equipamento (incluindo falha de casco), seguindo por colisões/abalroamento, sendo que a maioria desses navios envolvidos nas ocorrências tinham mais de 20 (vinte) anos de idade.

Quanto aos dutos, uma pesquisa realizada por Siler-Evans et al. (2014) apontou que enquanto no resto no mundo algo entorno de $49 \%$ é provocado por falha de equipamento/material. Outro dado importante obtido é que, apesar da quantidade de incidentes ter diminuído da década de 70 até o início do ano 2000, a média de incidentes (algo entorno de 100 por ano) pouco se alterou desde então.

Quanto aos locais de ocorrências de cenários potenciais ou efetivos de derrame de óleo no mar, estes foram divididos em relação a proximidade das seguintes áreas: Baia de São Marcos (canal de acesso e bacia de evolução, inclusive perto de bancos de areia), Porto do Itaqui (faixa de dutos, vias de circulação de veículos e interface terra/mar dos berços de atracação), Terminal Alumar (interface terra/mar dos berços de atracação) e Terminal VALE (interface terra/mar dos berços de atracação) (Gráfico 02).

O Porto do Itaqui apresentou cerca de $40 \%$ do total das ocorrências potenciais e efetivas de derrame de óleo no mar na região do Complexo Portuário de São Luís nos últimos 30 anos, sendo que a maior parte dessas ocorrências se deu durante a movimentação de cargas, através de dutos (líquidos combustíveis) e guindaste, além de manobras internas em um navio para movimentação de combustível (entre tanques).

Já a área da baia de São Marcos, principalmente próxima ao canal marítimo de acesso interno ao Complexo Portuário de São Luís, ficou em segundo lugar no ranking dos locais de ocorrência de cenários potenciais e efetivos de derrame de óleo na região do Complexo de São Luís, sendo que três dessas ocorrências se deram por encalhes em bancos de areia enquanto que outras duas foram em decorrência de abalroamento (choque entre embarcações).

Em seguida, foi registrado que o Porto de Ponta da Madeira apresentou três ocorrências com alta probabilidade de derrame de grandes volumes (superiores a duzentos metros cúbicos) em suas instalações, pelo fato de envolver dois navios de grande porte (um pela má distribuição da carga e outro por problemas estruturais do próprio navio) e uma plataforma para realização de obras marítimas.

Por último, no Terminal da ALUMAR houve uma pequena ocorrência envolvendo um pequeno derrame (menor que oito metros cúbicos), a partir de um navio atracado em seu berço, que se originou de uma falha no sistema de resfriamento do gerador de gás inerte. No entanto, ressalta-se que, apesar de somente ter sido registrado uma ocorrência derrame de óleo neste Terminal, nos últimos trinta anos, um outro navio que se dirigia ao Terminal da ALUMAR, levando carga de bauxita para esta indústria, chocou-se contra um banco de areia, porém esta ocorrência foi classificada como sendo na localidade da Baia de São Marcos. 
VI CIDESPORT/2019

Congresso Internacional

de Desempenho Portuário

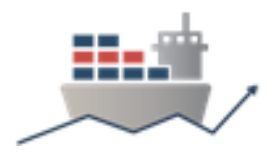

Gráfico 02 - Percentual dos locais de ocorrências de cenários potenciais ou efetivos de derrame de óleo no mar na região do Complexo Portuário de São Luís (1987-

2017).

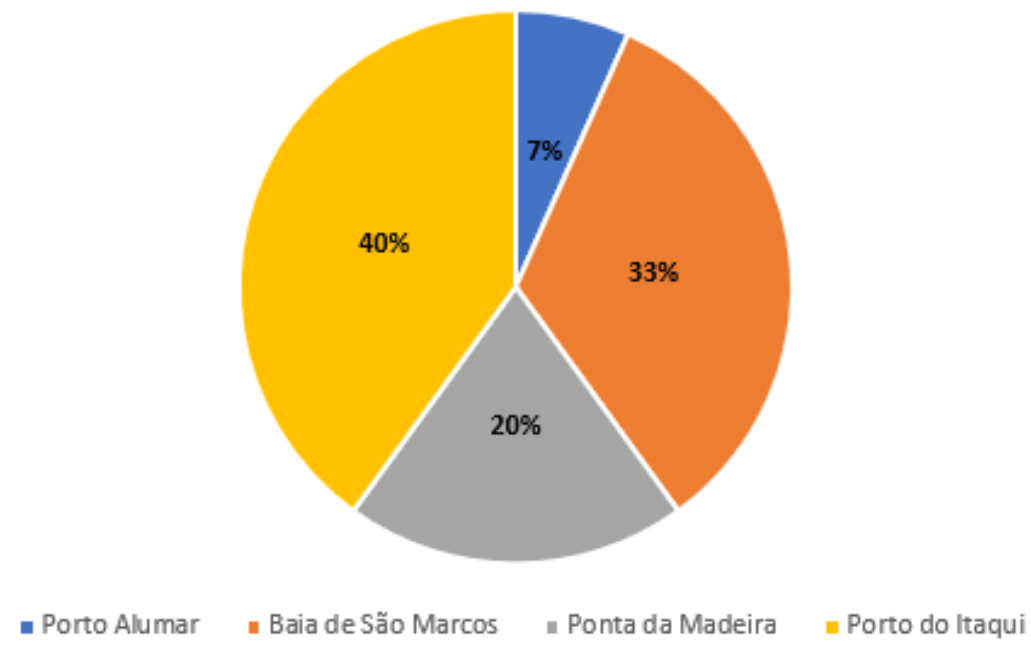

Fonte: Dados da pesquisa.

Sobre importância dos acidentes envolvendo derrame de líquidos nos corpos hídricos pela atividade portuária, Darbra et al. (2005), em um estudo comparando os aspectos ambientais mais significantes para a operação portuária identificou que, em ordem crescente de importância, os três principais são: consumo de recursos, geração de resíduos e, em primeiro lugar, descargas para os corpos hídricos. Ainda de acordo com a pesquisa, tais lançamentos de líquidos na água, em geral, originam-se de operação de movimentação de carga e atividades de abastecimento na área organizada dos portos, além de estarem mencionados nos planos de emergências das autoridades portuárias.

Kwesi-Buor et al. (2016), através de um estudo de sistemas dinâmicos, identificou que, dentre os fatores que influenciam o atendimento a emergência relacionados as atividades portuárias, a própria operação da atividade marítimo portuária quanto as mudanças da tecnologia e atitude frente a prevenção ao risco influenciam diretamente no indicador de extensão do dano de um acidente ambiental, afetando também a precisão nas previsões de hipóteses acidentais nas atividades portuárias.

Além desses outros estudos em âmbito internacional, um resultado interessante encontrado em escala local, e na região do CPSL, foi evidenciado Cutrim et al. (2014) ao identificar que um dos fatores chave para a gestão adequada dos recursos hídricos em portos reside também no controle dos sistemas de drenagem de efluentes e águas pluviais, que podem conter resíduos oleosos, e que esses podem ser carreados indevidamente aos corpos hídricos nas proximidades.

Da mesma forma, Silva (2014) destaca também que vários portos no país não possuem plantas atualizadas da sua rede de drenagem de águas pluviais, o que pode levar ao desconhecimento das contribuições de resíduos oleosos oriundos de pátios de movimentação de cargas aos corpos hídricos da região. Em alguns casos, tais sistemas podem até ter algum tipo de equipamento para tratamento (exemplo: caixa separadora de água e óleo), mas que, em geral, não estão em pleno funcionamento por conta de manutenção inadequada.

Já o cálculo do espaço de tempo entre uma ocorrência e a seguinte, ou seja, frequência, foi estimada na unidade de tempo em "dias", alocando-se em 
quatorze classes, abrangendo as quinze ocorrências e a quantidade de dias transcorridos entre uma ocorrência e a seguinte (classe), sendo que o total de dias transcorridos entre a primeira e a última ocorrência nos últimos trinta anos, somam 11.118 dias (Gráfico 03).

Quanto as medidas extremas, o maior espaço de tempo transcorrido entre as ocorrências se deu na décima classe, com 2.220 dias, entre novembro de 2005 e dezembro de 2011. Já o menor período entre as ocorrências foi registrado na penúltima classe, com 86 dias, entre os meses de setembro e dezembro de 2016.

Para as medias de tendência central Mediana e Média, foram obtidos, respectivamente, os seguintes valores: 580,5 dias medianos entre as ocorrências e 794,1 dias médios entre as ocorrências. Ao transformar esses valores de tendência central, em dias, para anos e meses, resulta que, nos últimos trinta anos, a possibilidade mediana de ocorrência de cenário potenciais ou efetivos de derrame de óleo no mar resultou em, aproximadamente, um ano e sete meses, enquanto que a possibilidade média ficou em cerca de dois anos e dois meses.

Gráfico 03 - Quantidade de dias entre cada ocorrência dos cenários, potenciais ou efetivos, de derrame de óleo no mar na região do Complexo Portuário de São Luís (1987-2017).

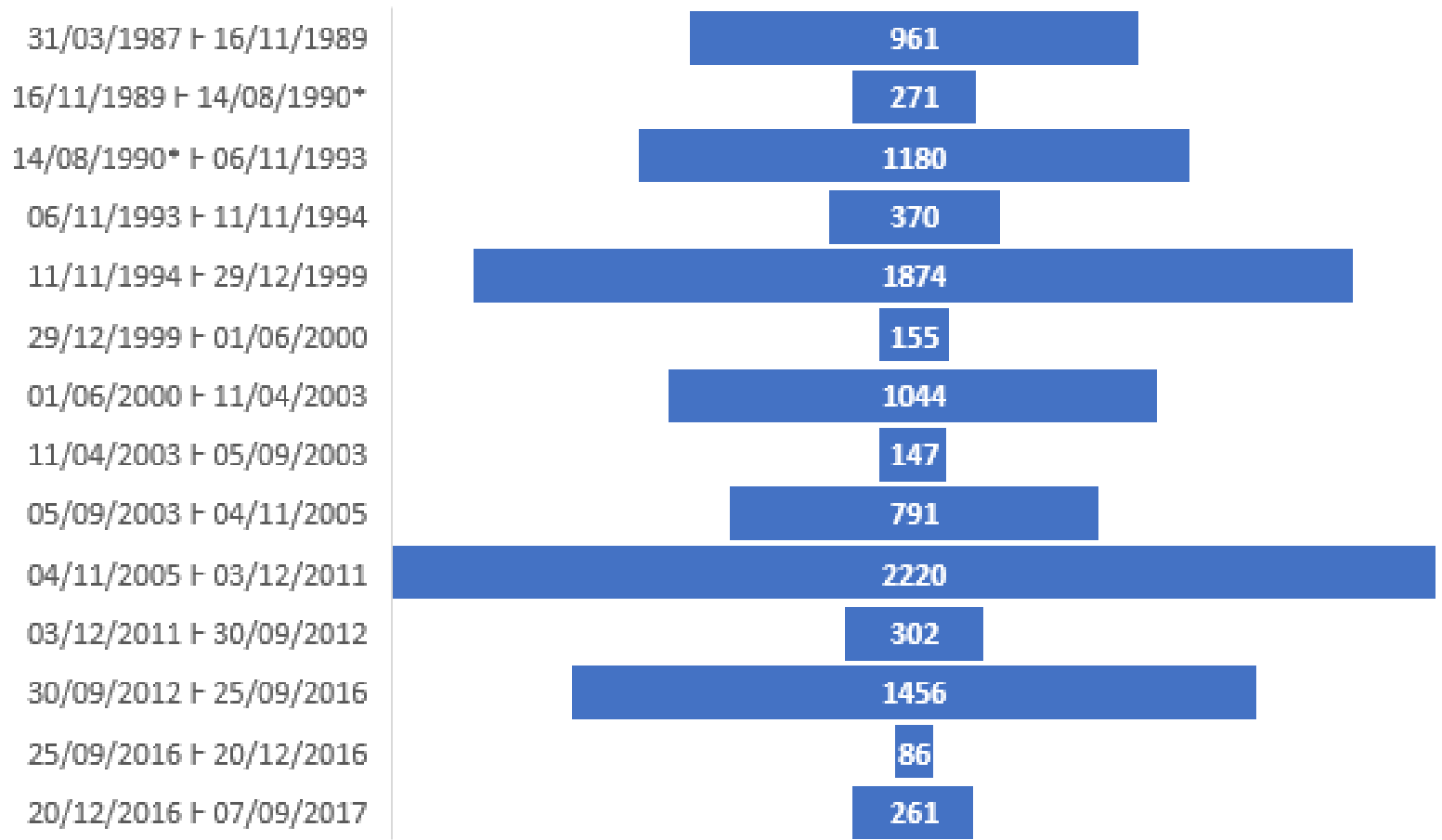

- Data estimada com base na média dos outros eventos, tendo em vista que na noticia somente foi informada o ano Fonte: Dados da pesquisa.

O Gráfico 03 constatou também que o período que registrou a maior quantidade de ocorrências foi o quarto trimestre, com um total de sete registros, representando quase metade do total das ocorrências em relação aos outros trimestres. Em seguida, o terceiro trimestre registrou cinco ocorrências, representando assim um terço da totalidade dos acidentes e incidentes com possibilidade de derrame de óleo no mar. O segundo e o primeiro trimestre, respectivamente, ficaram em penúltimo e último lugar na quantidade de ocorrências, sendo apenas duas no segundo trimestre e uma no primeiro trimestre. 
Já na região norte do estado de São Paulo, em uma análise histórica dos acidentes envolvendo derrame de óleo em um litoral brasileiro durante um período de 25 anos, Poffo (2002) identificou que, do final da década de 70 até o início da década de 90 houve um crescimento progressivo, mas que até cerca do final de 1999 ocorreu um decréscimo dessas ocorrências.

Um estudo feito por Borges et al. (2017), através de notícias de jornais que divulgaram acidentes no Brasil num período de 15 anos, 2000-2015, mostrou que são dados maior destaque para os acidentes de maior proporção ou de empresas de grande porte, sendo que, no entanto, existem diversas empresas que geram acidentes ambientais de pequena magnitude, mas de modo constante, o que pode levar a impacto tão significativo quanto o de um grande e único acidente maior.

Os volumes estimados possivelmente vazados (baseados exclusivamente nas informações constantes nas notícias veiculadas e/ou tomando como referência os volumes de pior caso para navio previstos nos PEls) das ocorrências de cenários potenciais ou efetivos de derrame de óleo no mar, foram divididas quanto a classificação prevista na Resolução CONAMA n 398/2008: incidente sem vazamento ou não informado (quando subentende-se que, ainda assim, houve um derrame de óleo oriundo de sistemas de lubrificação de outras peças fora do motor de combustão ou mesmo quando o próprio motor a combustão for considerado de pequeno porte), pequeno (até oito metros cúbicos), médio (maior que oito até a faixa de duzentos metros cúbicos) e grande (maior que duzentos metros cúbicos) (Gráfico 04).

Gráfico 04 - Portes (grande, médio, pequeno e "não informado") dos volumes de óleo possivelmente vazados dos cenários, potenciais ou efetivos, de derrame de óleo no mar na região da baía de São Marcos - MA (1987-2017).

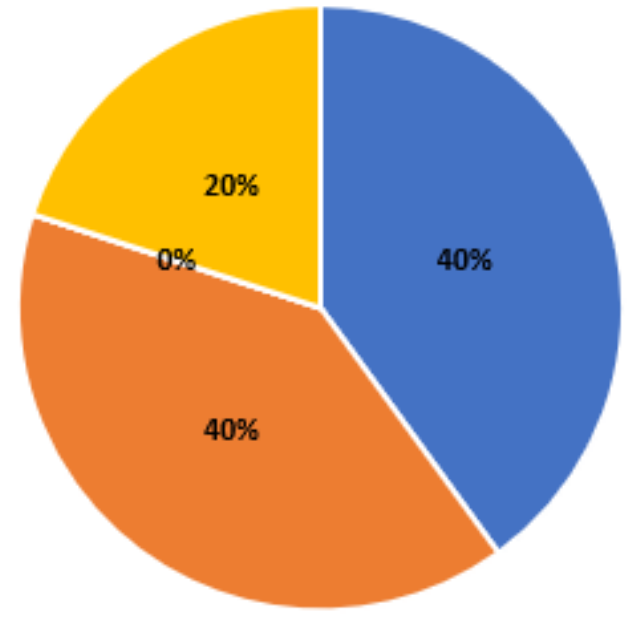

- Não informado/incidente "sem vazamento" |- Pequeno normal | Médio |

Fonte: Dados da pesquisa.

Os acidentes e incidentes no qual não tiveram nenhum tipo de derrame de óleo ou no qual as notícias não informaram sobre tal ocorrência somaram 6 (seis) registros nos últimos trinta anos na região da área pesquisada. Já os considerados como pequenos vazamentos totalizaram também seis registros, sendo três oriundos de oleodutos, outros dois de vazamentos internos de navios e mais um originário da adernação de uma pequena embarcação. Não foi encontrado nenhuma ocorrência passível de enquadrá-la como de médio porte. 


\section{CIDESPORT/2019 \\ Congresso Internacional \\ de Desempenho Portuário}

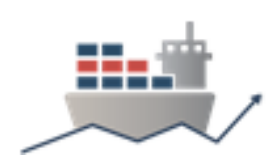

Quanto aos volumes de derramamento considerados de grande porte, ou seja, com volumes superiores a $200 \mathrm{~m}^{3}$ (duzentos metros cúbicos), as notícias e informações sobre os casos não apresentaram, diretamente, um volume superior para esse porte, no entanto, tentou-se inferir (através de estimativas) uma possível quantidade mínima vazada a partir das seguintes premissas relativas aos casos que não se enquadraram em nenhuma das outras categorias (vazamento não informado, pequeno e médio vazamento):

1 - Navio envolvido na ocorrência no ano de 1987: Como não foi indicado nas notícias o valor do combustível vazado (e nem tampouco foi encontrada informação de que houve a retirada total de óleos dos tanques e demais compartimentos que armazenem esse tipo de produto), tendo em vista que houve um naufrágio logo após o navio sair carregado de minério, estimou-se esse volume pautado nas hipóteses acidentais constantes nos PEls de um TUP e de um operador portuário do CPSL, ambos com valores de pior caso superior a $200 \mathrm{~m}^{3}$, e que operam navios com essa carga;

2 - Navio envolvido na ocorrência no ano de 1989: Como não foi indicado nas notícias o valor do combustível vazado (e nem tampouco foi encontrada informação de que houve a retirada total de óleos dos tanques e demais compartimentos que armazenem esse tipo de produto), tendo em vista que houve um naufrágio logo um pouco antes do navio chegar ao seu destino, estimou-se esse volume pautado nas hipóteses acidentais constantes no PEI de um TUP, com valores de pior caso superior a $200 \mathrm{~m}^{3}$, do CPSL que opera navio com essa carga;

3 - Navio envolvido na ocorrência no ano de 1990: Como não foi indicado o valor do combustível vazado (e nem tampouco foi encontrada informação de que houve a retirada total de óleos dos tanques e demais compartimentos que armazenem esse tipo de produto) em termos de volume, mas sim de massa, e ainda sim somente "parte" dela (estimando-se que essa parte residual que restou nos tanques seja equivalente a sexta parte), foi necessário estimar o volume $\left(\mathrm{em} \mathrm{m}^{3}\right)$ a partir da relação deste com a massa específica do produto vazado (massa específica estimada do óleo diesel $=815 \mathrm{~kg} / \mathrm{m}^{3}$ ), dividindo-se assim a massa total nos tanques pela massa específica do óleo diesel, depois multiplicando-se esse valor por 1/6, resultando em um volume de $6.748 \mathrm{~m}^{3}$, ou seja, valor esse próximo aquele informado no $\mathrm{PEI}$ do porto público do CPLS para navios petroleiros $\left(10.000 \mathrm{~m}^{3}\right)$ e assim, superior a $200 \mathrm{~m}^{3}$.

Os resultados encontrados no Gráfico 4, em especial relativo as ocorrencias com oleodutos, estão em sintonia com aqueles apontados por Cunha (2014) que, comparando os incidentes de oleodutos nos Estados Unidos, Canadá Europa e Brasil, percebeu-se que cerca de um terço (algo entorno de 30\%) dos incidentes envolvendo derrame de óleo a partir de dutos geram pequenos volumes, ou seja, de 1 a $5 \mathrm{~m} 3$

Da mesma forma, em um estudo feito pelo ITOPF (2017), desde a década de 1970 até 2017 , com registros de vazamento de óleo de navios petroleiros de todo o mundo, foi identificado que a principal causa de vazamento de óleo, considerados de pequeno e médio porte originou-se de falha de equipamentos em operação de carregamento/descarregamento, enquanto que os vazamentos de grande porte resultaram, em sua maioria, de colisão/abalroamento/encalhe durante a navegação (navio não ancorado).

Quanto a questão dos dados informados às autoridades portuárias sobre ocorrências ambientais, Serrano et al. (2018), em uma pesquisa realizada com os principais portos espanhóis, utilizando-se da metodologia de Rede Bayesiana, através 


\section{CIDESPORT/2019 \\ Congresso Internacional \\ de Desempenho Portuário}

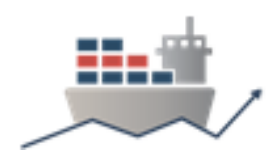

da análise de indicadores de sustentabilidade (econômicos, sociais, ambientais e institucionais) determinados pelo órgão gestor portuário espanhol, encontrou uma forte associação entre as questões de segurança ocupacional e aquelas relacionadas a qualidade da água, em especial relativas a descargas em ambientes aquáticos.

Por outro lado, um estudo conduzido por Antão et al. (2016)., de 2013 a 2017, com diversos portos europeus e de outros países (que publicavam informações na internet em língua inglesa) identificou que os aspectos relacionados a gestão de saúde, segurança ocupacional, segurança patrimonial e meio ambiente são extremamente importantes, não somente para o atendimento de questões legais, mas principalmente para a diminuição de custos operacionais e redução de acidentes. $O$ estudo destaca ainda que, nos aspectos de segurança ocupacional, os indicadores de número de acidentes náuticos e quantidade de vazamentos aparecem entre os 10 mais frequentes indicadores portuários da amostra.

\section{CONCLUSÕES}

Os sistemas de transportes surgiram durante o período chamado de préindustrial, com o objetivo de facilitar o escoamento do excedente alimentar, sendo que no início dessa fase esse sistema era extremamente rudimentar, tanto que o transporte de pessoas era ínfimo, até porque as elites locais habitavam predominantemente os centros urbanos.

Devido globalização da economia, ligada a uma maior competitividade em escala mundial, há cada vez mais uma alta pressão dos concorrentes empresariais em reduzir seus custos relativos ao transporte e movimentação de cargas. Logo, os sistemas de transporte marítimo apresentam-se como uma alternativa a essas questões, conectando regiões e oferecendo um meio seguro e econômico para o transporte de matérias-primas e produtos acabados (ALFREDINI \& ARASAKI, 2009).

Assim, os derivados de petróleo tornaram-se o principal tipo de combustível utilizado no transporte marítimo e é primordial esclarecer que toda a movimentação de importação e exportação desse produto ocorre através dos portos, no qual os cinco principais portos de entrada desses derivados de petróleo são os das cidades de: Paranaguá, Santos, Rio de Janeiro, Suape e, principalmente, São Luís, que ocupa o primeiro lugar na movimentação de gasolina e diesel para os anos bases de 2015 e 2016 (ANP, 2017).

Nesse sentido, esta pesquisa buscou abordar como o gerenciamento de riscos ambientais do derrame de óleo no mar é tratado nas empresas localizadas no Complexo Portuário de São Luís (CPSL), através das notícias e informes sobre incidentes marítimos/ portuários com óleo ocorridos nessa região nos últimos 30 anos.

Dentre as principais fontes de incidentes envolvendo derrame de óleo na região do CPSL, o presente trabalho identificou, através das notícias, que a maioria dessas ocorrências envolveu navios e dutos, sendo que esse resultado está alinhado com o que foi encontrado na análise das mesmas fontes dos PEI e dos relatos dos gestores ambientais portuários. Quantos aos portes dos volumes de derrame de óleo, grande parte do que foi noticiado enquadra-se como de pequeno porte (até $8 \mathrm{~m}^{3}$ ), enquanto que a maioria dos $\mathrm{PEI}$ aponta para vazamentos de grande porte (superiores a $200 \mathrm{~m}^{3}$ ), o que demostra, aparentemente, a preocupação dos consultores em considerar os cenários de pior caso dentre as hipóteses acidentais.

Quanto aos locais e periodicidades identificados nas notícias, registrou-se que o local no qual mais ocorreu algum evento com possibilidade de derrame de óleo na região do CPSL foi no Porto do Itaqui, devido a contribuição de dutos e outras 


\section{CIDESPORT/2019 \\ Congresso Internacional \\ de Desempenho Portuário}

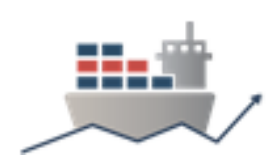

pequenas embarcações e equipamentos. Já o segundo local mais afetado diretamente por tais eventos foi a baia de São Marcos, principalmente no trecho da bacia de evolução/canal de acesso interno, envolvendo, principalmente, navios. Dessa forma, a média histórica estimada, encontrada dentre as ocorrências de derrame de óleo no CPSL, foi de 2,2 anos.

Conclui-se, portanto, que, sob a ótica do histórico noticiado de acidentes na baia de São Marcos, houve uma diminuição dos acidentes e incidentes que envolveram possíveis grandes e médios vazamentos de derrame de óleo no mar nessa região, além do aumento da sensibilização da importância do gerenciamento de risco (evidenciados através dos dados dos relatórios de sustentabilidade dos portos e instalações portuárias do CPSL). No entanto, vale ressaltar a necessidade do aprimoramento, por parte de todas as empresas da região, dos sistemas de gestão de riscos destes cenários, principalmente na prevenção de vazamentos considerados de pequeno porte.

As limitações dessa pesquisa estão na não abordagem de manchas órfãs e nem utilizou dados históricos oficiais e não investigação das causas e consequências dos acidentes com derrame de óleo ao mar.

Os possíveis desdobramentos dessa pesquisa estão relacionados com a análise das prováveis causas dos acidentes, investigação das suas consequências e ampliação da pesquisa documental.

\section{REFERÊNCIAS}

Agência Nacional do Petróleo, Gás Natural e Biocombustíveis (ANP). Panorama do abastecimento de combustíveis: 2017. Agência Nacional do Petróleo, Gás Natural e Biocombustíveis. - Rio de Janeiro: ANP, 2017. Disponível em:

<http://www.anp.gov.br/images/publicacoes/livros e revistas/Panorama do Abastec imento2017.pdf> Acesso em: 09 jun. 2018.

ALFREDINI, P.; ARASAKI, E. Obras e gestão de portos e costa: a técnica aliada ao enfoque logístico e ambiental. $2^{\circ}$ ed. São Paulo: Edgard Blucher, 2009. 776p

ALUMAR. Ofício SSMA_ABS/026/2017. São Luís: ALUMAR, 2017.

ANTÃO, P.; CALDERÓN, M.; PUIG, M.; MICHAIL, A.; WOOLDRIDGE, C.; DARBRA, R. M. Identification of Occupational Health, Safety, Security (OHSS) and Environmental Performance Indicators in port areas. Safety Science 85 (2016) 266-275

AZOUBEL, D. FOTOGRAFIA NO MARANHÃO: PERSPECTIVA HISTÓRICA E PERCURSO DE DREYFUS NABOR AZOUBEL. REVISTA CAMBIASSU, São Luís MA, Ano XVIII, No 4 - Janeiro a Dezembro de 2008, 51-74

AZOUBEL, D. MARIA CELESTE: análise semiótica da capa do Jornal do Povo, de 19 de março de 1954. Anais, $40^{\circ}$ Congresso Brasileiro de Ciências da Comunicação - INTERCOM, Curitiba - PR - 04 a 09/09/2017, 1-15

Banco do Nordeste do Brasil S/A. Manual de Impactos Ambientais: orientações básicas sobre aspectos ambientais de atividades produtivas. Fortaleza: BNB, 1999. 297p 
VI CIDESPORT/2019

Congresso Internacional

de Desempenho Portuário

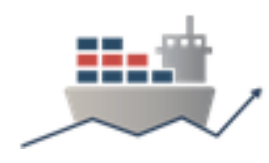

BORGES, L. M.; FERREIRA, J. S.; ROVER, S. Divulgação de acidentes ambientais no Brasil: uma análise a partir de notícias de jornais de grande circulação. RMC, Revista Mineira de Contabilidade, v. 18, n. 3, art. 1, p. 5-15, set./dez. 2017

CASTRO, P.; HUBER, M. E. Biologia Marinha. $8^{\circ}$ ed. Porto Alegre: AMGH, 2012. $461 \mathrm{p}$

CUNHA, S. B. A review of quantitative risk assessment of onshore pipelines. Journal of Loss Prevention in the Process Industries 44 (2016) 282e298

CUTRIM, S. S.; PARENTE, F. R. F.; ROBLES, L. T. GESTÃO DE RECURSOS HÍDRICOS EM UM TERMINAL PORTUÁRIO. TECNO-LÓGICA, Santa Cruz do Sul, v. 18 , n. 1 , p. $24-36$, jan./jun. 2014

DARBRA, R.M.; RONZA, A.; STOJANOVIC, T.A.; WOOLDRIDGE, C.; CASAL, J. A procedure for identifying significant environmental aspects in sea ports. Marine Pollution Bulletin 50 (2005) 866-874

Ecopress. Falha humana provoca vazamento de óleo no MA. São Paulo:

Ecopress, 2000. Disponível em:

$<$ http://www.ecopress.jex.com.br/eco+watch/falha+humana+provoca+vazamento+de +oleo+no+ma> Acesso em: 09 jun. 2018.

ELIOPOULOU; PAPANIKOLAOU, A.; VOULGARELLIS, M.. Statistical analysis of ship accidents and review of safety level. Safety Science 85 (2016) 282-292 Empresa de Pesquisa Energética (EPE). Balanço Energético Nacional 2017. Ano base 2016 / Empresa de Pesquisa Energética. - Rio de Janeiro: EPE, 2017.

Disponível em: <http://epe.gov.br/sites-pt/publicacoes-dadosabertos/publicacoes/PublicacoesArquivos/publicacao-46/topico82/Relatorio Final BEN 2017.pdf>Acesso em: 09 jun. 2018.

Empresa Maranhense de Administração Portuária (EMAP). Formulário para registro de acidentes ambientais no: 004 /2016. São Luís: EMAP, 2016.

Empresa Maranhense de Administração Portuária (EMAP). Plano de Desenvolvimento e Zoneamento do Porto Do Itaqui - PDZ ITAQUI. São Luís: EMAP, 2012.

Folha de São Paulo. Navio que partiu ao meio não será removido. São Paulo: Jornal Folha de São Paulo, 1994. Disponível em:

<https://www1.folha.uol.com.br/fsp/1994/12/06/cotidiano/25.html>. Acesso em: 14 jul. 2018.

Folha de São Paulo. Óleo vaza de terminal em São Luís (MA). São Paulo: Jornal Folha de São Paulo, 1999. Disponível em:

<https://www1.folha.uol.com.br/fsp/cotidian/ff3112199912.htm>. Acesso em: 14 jul. 2018.

G1 Maranhão. Guindaste pega fogo no Porto do Itaqui, em São Luís. São Luís: G1 Maranhão, 2016. Disponível em: 
<http://g1.globo.com/ma/maranhao/noticia/2016/09/guindaste-pega-fogo-no-porto-do-itaqui-emsao-luis.html>. Acesso em: 14 jul. 2018.

HINRICHS, R. A. \& KLEINBACH, M. Energia e Meio Ambiente. São Paulo: Pioneira Thomson Learning, 2003. 543p

Imirante. Barco pesqueiro naufraga na Baía de São Marcos: 0 acidente aconteceu após um choque com navio de Taiwan. São Luís: Imirante, 2003. Disponível em: <http://imirante.com/sao-luis/noticias/2003/04/13/barco-pesqueironaufraga-na-baia-de-sao-marcos.shtml>. Acesso em: 14 jul. 2018.

Imirante. Controlado vazamento de óleo em navio no Porto do Itaqui. São Luís: Imirante, 2003. <http://imirante.com/sao-luis/noticias/2003/09/05/controladovazamento-de-oleo-em-navio-no-porto-do-itaqui.shtml>. Acesso em: 14 jul. 2018.

Instituto Brasileiro do Meio Ambiente e dos Recursos Naturais Renováveis (IBAMA). Relatório de Acidentes Ambientais - 2009. Brasília: IBAMA, 2010. Disponível em $<$ <ttp://www.ibama.gov.br>. Acesso em 20/04/2018.

Jornal da Globo. Plataforma afunda no Maranhão com $\mathbf{3 0}$ mil litros de óleo diesel. Rio de Janeiro: Jornal da Globo, 2012. Disponível em:

$<$ http://g1.globo.com/jomal-da-globo/noticia/2012/10/plataforma-afunda-no-maranhao-com-30mil-litros-de-oleo-diesel.html>. Acesso em: 14 jul. 2018.

Jornal do Brasil. Navio (Trombetas - Norsul) encalha em banco de areia no Maranhão e pode partir-se ao meio. Rio de Janeiro: Jornal do Brasil, 1989. Disponível em: <http://memoria.bn.br/pdf/030015/per030015 1989 00223.pdf>. Acesso em: 14 jul. 2018.

Jornal Pequeno. Defeito em tubulação provoca vazamento no Porto do Itaqui. São Luís: Jornal Pequeno, 2005. Disponível em: $<$ https://edicao.jornalpequeno.com.br/impresso/2005/11/05/defeito-em-tubulacaoprovoca-vazamento-no-porto-do-itaqui/>. Acesso em: 14 jul. 2018.

Jornal Pequeno. Lembranças de repórter (encalhe do navio coreano Hyundai New World, 1987). São Luís: Jornal Pequeno, 2011. Disponível em: $<$ https://edicao.jornalpequeno.com.br/impresso/2011/06/19/lembrancas-de-reporter8/>. Acesso em: 14 jul. 2018.

KITZMANN, D.; ASMUS, M. Gestão ambiental portuária: desafios e possibilidades. Rio de Janeiro: RAP, 2006. Disponível em < http://www.scielo.br/pdf/rap/v40n6/06.pdf >. Acesso em 20/04/2018.

KWESI-BUOR, J.; MENACHOF, D. A.; TALAS, R. Scenario analysis and disaster preparedness for port and maritimelogistics risk management. Accident Analysis and Prevention (2016). http://dx.doi.org/10.1016/j.aap.2016.07.013

O Estado do Maranhão. Risco de naufrágio mantém navio no Terminal Ponta da Madeira. São Luís: Jornal O Estado do Maranhão, 2011. Disponível em: 
VI CIDESPORT/2019

Congresso Internacional

de Desempenho Portuário

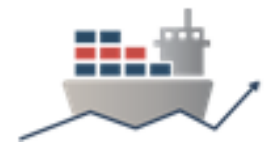

<http://imirante.com/oestadoma/online/06122011/pdf/p10.pdf>. Acesso em: 14 jul. 2018.

POFFO, Í. R. F. Vazamentos de Óleo no Litoral Norte do Estado de São Paulo: Análise Histórica (1974 a 1999). In: Construindo a Ciência Ambiental.

ABRAMOVAY, R. (org.) São Paulo, SP: Annablume - FAPESP, 2002. 438 p.

POFFO, Í. R. F. Vazamentos de Óleo no Litoral Norte do Estado de São Paulo: Análise Histórica (1974 a 1999). In: Construindo a Ciência Ambiental.

ABRAMOVAY, R. (org.) São Paulo, SP: Annablume - FAPESP, 2002. 438 p (235263)

PortosMA. Os maiores acidentes já registrados no complexo portuário do estado do Maranhão. São Luís: PortosMA, 2018. Disponível em:

<http://www.portosma.com.br/fotos/trade/acidentes.php>. Acesso em: 14 jul. 2018.

SÁNCHEZ, L. E. Avaliação de impacto ambiental: conceitos e métodos. São Paulo: Oficina de Textos, 2006. 495p

SERRANO, B. M.; CANCELAS, N. G.; FLORES, F. S.; ORIVE, A. C. Classification and prediction of port variables using Bayesian Networks. Transport Policy 67 (2018) 57-66

SILER-EVANS, K.; HANSON, A.; SUNDAY, C.; LEONARD, N.; TUMMINELLO, M. Analysis of pipeline acidentes in the United States from 1968 to 2009.

International jornal of critical infrastructure protection 7 (2014) 257-269

SILVA, C. C. A. Gerenciamento de Riscos Ambientais. In: JÚNIOR, A. P.;

ROMÉRO, M. A.; BRUNA, G. C (coord.). Curso de Gestão Ambiental. Barueri - SP: Manole, 2004. 1045p

SILVA, V. G. Sustentabilidade em portos marítimos organizados no Brasil: discussão para implantação de um sistema de indicadores de desempenho ambiental. Dissertação (Mestrado em Planejamento Energético). 118 p.

Universidade Federal do Rio de Janeiro, Rio de Janeiro, 2014

SPIRO, T. G; STIGLIANI, W. M. Química ambiental. $2^{\circ}$ ed. São Paulo: Pearson Prentice Hall, 2009. 334p

SZKLO, A. S.; ULLER, V. C. Fundamentos do refino de petróleo: tecnologia e economia. $2^{\circ}$ ed. Rio de Janeiro: Interciência, 2008. 285p

Terra. Petrobras é multada por vazamento de óleo no MA. São Paulo: Terra, 2005. Disponível em: <http://noticias.terra.com.br/brasil/noticias/0, Ol740629-El714,00Petrobras+e+multada+por+vazamento+de+oleo+no+MA.html>. Acesso em: 14 jul. 2018.

THE INTERNATIONAL TANKER OWNERS POLLUTION FEDERATION LIMITED (ITOPF). Oil tanker spill statistics 2017. London: ITOPF, 2017. Disponível em: <http://www.itopf.com>. Acesso em: 28 jul. 2018. 


\section{CIDESPORT/2019 \\ Congresso Internacional \\ de Desempenho Portuário}

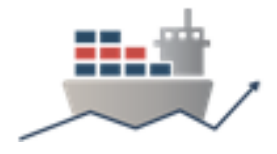

THOMAS, J. E. Fundamentos de Engenharia de Petróleo. $2^{\circ}$ ed. Rio de Janeiro: Interciência, 2004. 271p

Tribunal Marítimo. Processo $n^{0} 16.413$ - avaria e naufrágio parcial do navio Trade Daring. Rio de Janeiro: O Tribunal, 2014. Disponível em:

$<$ https://www.marinha.mil.br/tm/sites/www.marinha.mil.br.tm/files/file/biblioteca/livros/l ivro 80anos TM web.pdf>. Acesso em: 14 jul. 2018.

VIDIGAL, A. A. F. (et al). Amazônia Azul: o mar que nos pertence. Rio de Janeiro: Record, 2006. 305p 